\title{
Fatty acid profile of Longissimus dorsi muscle of crossbred pigs fed with addition of conjugated linoleic acid or sunflower oil
}

Przemysław Dariusz Wasilewski', Jerzy Nowachowicz'1, Grażyna Michalska', Tomasz Bucek', Brendan Lynch², Anne Marie Mullen³

'University of Technology and Life Sciences in Bydgoszcz, Faculty of Animal Breeding and Biology, Department of Animal Products Evaluation, Bydgoszcz, Poland, '2Moorepark Pig Production Centre, Teagasc, Fermoy, Co. Cork, Ireland, ${ }^{3}$ Ashtown Food Research Centre, Ashtown, Dublin, Ireland

\begin{abstract}
The aim of the paper was to investigate the impact of feeding pigs with different levels of conjugated linoleic acid or sunflower oil on fatty acid profile of Longissimus dorsi muscle. The subjects of research were 60 crossbred gilts divided into 6 groups, fed with different levels of conjugated linoleic acid (CLA) or sunflower oil (SFO) $(0.5 ; 1.0$ and $2.0 \%$, respectively). All fatteners were kept and fed under standardized conditions. Animals were slaughtered at $95 \mathrm{~kg}$ of body weight. Fatty acid profile was determined in samples of Longissimus dorsi muscle from each animal. Gas chromatography was used (in the research). The significance of differences between groups was verified by Duncan's test. In the present study the addition of conjugated linoleic acid or sunflower oil did not impact the composition and amounts of saturated or unsaturated fatty acids in Longissimus dorsi muscle.
\end{abstract}

Keywords: conjugated linoleic acid, sunflower oil, pigs, fatty acid profile, Longissimus dorsi

\section{Zusammenfassung}

\section{Fettsäureprofil des Musculus longissimus dorsi von Schweinen, deren Futter mit konjugierter Linolsäure oder Sonnenblumenöl ergänzt wurde}

Ziel war die Untersuchung des Einflusses von konjugierter Linolsäure und Sonnenblumenöl als Futterergänzung auf das Fettsäureprofil des M. longissimus dorsi beim Schwein. Sechzig weibliche Kreuzungsmastschweine wurden einheitlich gehalten und in sechs Gruppen geteilt deren Futterrationen mit jeweils 0,5; 1,0 oder 2\% einer der beiden Zusätze ergänzt wurden. Bei einem Schlachtgewicht von $95 \mathrm{~kg}$ wurde das Fettsäureprofil des Muskels jedes Tieres mittels Gaschromatographie bestimmt. In vorliegender Untersuchung konnten keine signifikanten Einflüsse der beiden Futterzusätze auf das Fettsäureprofil im M. longissimus dorsi nachgewiesen werden.

Schlüsselwörter: konjugierte Linolsäure, Sonnenblumenöl, Schwein, Fettsäureprofil, Muskulus longissimus dorsi 


\section{Introduction}

Conjugated linoleic acid is anti-cancerogenic, prevents fat deposition and arteriosclerosis, stimulates the immune system and has anti-inflammatory properties (Basu et al. 2000, MacDonald 2000, McCarty 2000, Kritchevsky 2000, Watkins \& Seifert 2000, PanczenkoKresowska \& Ziemlański 2001, Pfeuffer 2001, Bassaganya-Riera et al. 2002, Hontecillas et al. 2002, Whigham et al. 2002, Bawa 2003, Ip et al. 2003). Dietetic value of pork depends on carcass fat content and on fatty acid profile, especially on hypocholesterolemic acids. Many factors influence fatty acid profile of pig tissue i.e. genetics (breed) and environment, including feeding (Raj et al. 2004) and also growth and development of experimental animals (Walkiewicz et al. 2001, Missotten et al. 2008). It was stated that a decreased cholesterol level in fat tissue can be achieved by enriching it with polyunsaturated fatty acids (Barowicz \& Kędzior 2000, Kołodziej et al. 2002, Flis et al. 2007, Peinado et al. 2009). Pieszka et al. (2004) noticed a decrease of triglycerides, total cholesterol and its HDL fraction due to conjugated linoleic acid (CLA) added to the diet.

Dietetic pork should have an optimal level of intra- and intermuscular fat with a beneficial fatty acid profile, especially with respect to the amount and proportion of omega- 3 and omega-6 polyunsaturated fatty acids. Pork taste is positively correlated with the amount of saturated fatty acids (SFA) and monounsaturated fatty acids (MUFA), negatively with the amount of polyunsaturated fatty acids (PUFA) (D'Souza \& Mullan 2002, Migdał et al. 2004).

Previous research shows that the ratio of unsaturated to saturated acids and the amount of essential fatty acids in loin fat and backfat depend on fatteners feeding, especially on the share in food doses of fodders with high amount of linoleic and linolenic acids (Migdał et al. 1999, Więcek et al. 2010).

Barowicz (2000) argues that calcium fatty acids salts, as an addition to fatteners fodder, can be one way to improve the nutritional properties of pork. Koczanowski et al. (2002) conclude that feeding fatteners with the fodder with the addition of soya oil resulted in a highly significant increase of PUFA amount and a small decrease of SFA and MUFA in Longissimus dorsi muscle.

The aim of the paper was to investigate the impact of feeding pigs with the fodder with different levels of conjugated linoleic acid or sunflower oil on fatty acid profile of Longissimus dorsi muscle.

\section{Material and methods}

The research was conducted between December 2003 and May 2004. The experiment covered 60 crossbred gilts, $\partial^{\lambda}$ Irish Landrace $\times q$ ( $\partial$ Irish Landrace $\times+$ Irish Large White). The pigs were fattened from $40 \mathrm{~kg}$ to $95 \mathrm{~kg}$ of body weight in a pig-house of Teagasc in Moorepark (Ireland). The pigs were kept and fed under standardised conditions. The animals were in $4.8 \mathrm{~m} \times 2.4 \mathrm{~m}$ boxes. Temperature ranged from 20 to $22^{\circ} \mathrm{C}$ and was computer-regulated (Steinen PCS 8200 Climate Controller).

The pigs were chosen at $40 \mathrm{~kg}$ of body weight and divided into 6 groups (10 individuals per group, 6 groups in total, each placed in a separate box). Diversed diets were used, as follows:

1. diet of $0.5 \%$ amount of conjugated linoleic acid (CLA 0.5 )

2. diet of $1.0 \%$ amount of conjugated linoleic acid (CLA 1.0) 
3. diet of $2.0 \%$ amount of conjugated linoleic acid (CLA 2.0)

4. diet of $0.5 \%$ amount of sunflower oil (SFO 0.5)

5. diet of $1.0 \%$ amount of sunflower oil (SFO 1.0)

6. diet of $2.0 \%$ amount of sunflower oil (SFO 2.0)

The source of conjugated linoleic acid was Luta-CLA 60 preparation made by BASF of CLA (C 18:2) containing min. $56 \%$, including $\mathrm{c} 9 \mathrm{t} 11$ isomer min. $28 \%$ and $\mathrm{t} 10 \mathrm{c} 12$ isomer $\min .28 \%$. After the end of fattening period, animals were carefully transported to Meat Production Plant Glanbia Meats in Edenderry (Ireland). The animals were slaughtered after $24 \mathrm{~h}$ of rest. Gas (CO2) stunning was used.

Fatty acid profile was determined in the samples of Longissimus dorsi muscle from each animal. Gas chromathography was used - Varian 3400 Gas Chromatograph, equipped with SGE BPX-70 column, 120 m length, 0.25 mm diameter (Phenomenex).

The results were statistically processed - mean $(\bar{x})$ and standard deviation (s) were calculated. The significance of differences between tested groups was verified by Duncan's test. A computer program STATISTICA 8.0 PL (2008) was used.

\section{Results}

The table presents the amount of fatty acids in Longissimus dorsi muscle. Saturated fatty acids (SFA) ranged from $43.71 \%$ (group 1) up to $46.24 \%$ (group 6). Statistically significant differences were not stated between the tested groups. However, one can observe a tendency of the amount of saturated fatty acids in Longissimus dorsi muscle to increase with the growing amount of conjugated linoleic acid or sunflower oil in fodder.

The concentration of unsaturated fatty acids (UFA) ranged from 53.76 (group 6) up to 56.29 (group 1). Although no statistically significant differences between tested groups of animals were observed, there was a tendency of the amount of unsaturated fatty acids in Longissimus dorsi muscle to decrease with the growing amount of conjugated linoleic acid or sunflower oil in diet.

Statistically significant differences between particular groups of pigs were observed in the case of monounsaturated fatty acids (MUFA) and polyunsaturated fatty acids (PUFA) being a total amount of unsaturated fatty acids in the tested material. The lowest concentration $(27.63 \%)$ of monounsaturated fatty acids was in group 6. Between this group and groups 1, 2 and 4, statistically significant differences were observed. The highest MUFA amount (34.99\%) was in group 4 . The differences between the results of group 4 and the results of pigs from groups 3 and 5 were statistically significant. In the case of monounsaturated fatty acids in groups of animals receiving conjugated linoleic acid or sunflower oil as fodder supplement, the lowest concentration was in pigs receiving particular supplement (CLA or SFO) of the highest dose.

The amount of polyunsaturated fatty acids (PUFA) in group 4 was the lowest $(20.01 \%)$. The highest amount $(26.13 \%)$ was in group 6 . The difference between these groups was statistically significant. The highest concentration of polyunsaturated fatty acids was in animals receiving conjugated fatty acid or sunflower oil as fodder supplement in the highest amount. 


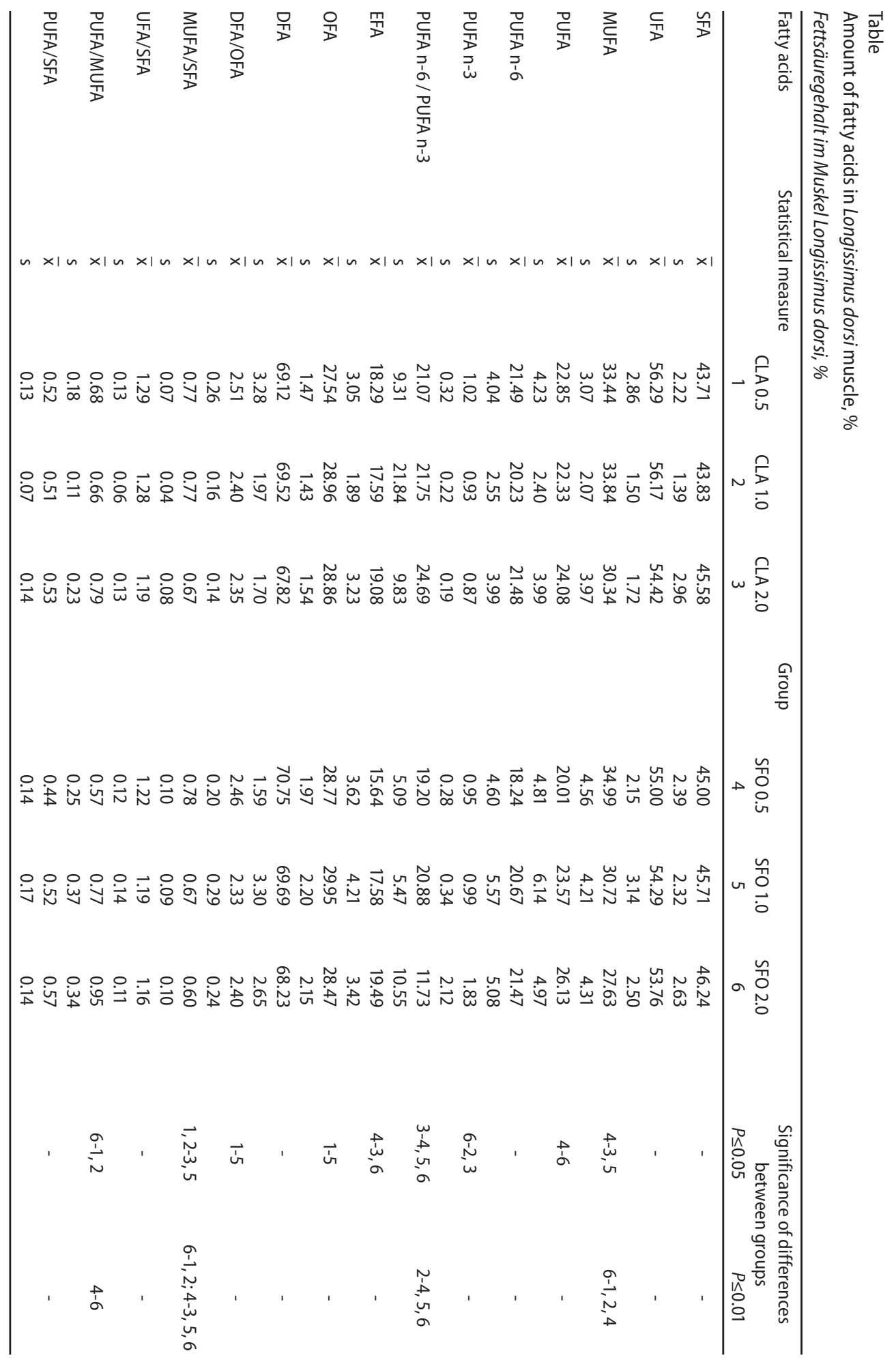


It was observed that a higher share (21.49\%) of $\mathrm{n}-6$ polyunsaturated fatty acids (PUFA $\mathrm{n}-6$ ) occured in the group of pigs receiving conjugated linoleic acid in the amount of $0.5 \%$. The lowest amount (18.24\%) was in the group of fatteners fed with the fodder of $0.5 \%$ addition of sunflower oil. This difference was not confirmed as statistically significant.

Polyunsaturated fatty acids from $n-3$ family (PUFA $n-3$ ) were in the highest amount $(1.83 \%)$ in group 6. The lowest amount ( 0.87 and $0.93 \%$ ) was observed in groups 3 and 2. Differences between group 6 and groups 2 and 3 were statistically significant.

The lowest ratio of PUFA $n-6$ to PUFA $n-3$ was in Longissimus dorsi muscle of animals receiving the addition of sunflower oil in the amount of $2 \%$. Statistically high significant differences in this range were observed between group 2 and groups 4,5 and 6 . Statistically significant differences occured between group 3 and groups 4,5 and 6 .

The highest concentration (19.49\% and $19.08 \%$ ) of essential fatty acids (EFA-C18:2+C18:3) was in groups 3 and 6 . The lowest concentration (15.64\%) was in group 4. The differences between group 4 and groups 3 and 6 were confirmed as statistically significant.

Hypercholesterolemic acids (OFA) were in the highest amount (29.95\%) in group 5 . The lowest amount (27.54\%) was in group 1. The differences between results of these groups of animals were statistically significant.

The level of neutral and hypocholesterolemic acids (DFA-C18:0+UFA) was not statistically diversed. The highest amount $(70.75 \%$ ) was in the group of animals receiving the addition of $0.5 \%$ sunflower oil into fodder. The lowest level $(67.82 \%$ and $68.23 \%)$ was observed in the group of pigs fed with $2 \%$ addition of conjugated linoleic acid and sunflower oil.

The lowest ratio of DFA to OFA acids (2.33) was in group 5, the highest (2.51) in group 1. The differences between these two groups were confirmed statistically $(P \leq 0.05)$.

In the case of MUFA and SFA the lowest ratio (0.60) was observed in group 6 , the highest (0.78) in group 4. Between group 6 and groups 1,2 and group 4 and groups 3, 5, 6 statistically high significant differences were observed. Between groups 1, 2 and 3, 5 statistically significant differences were confirmed.

The lowest ratio of UFA to SFA (1.16) was in group 6, the highest in (1.29) group 1. The differences between these groups were not confirmed statistically.

The lowest ratio of PUFA to MUFA was in group $4(0.57)$, the highest (0.95) in group 6. Between these groups a statistically significant difference was observed. Moreover, between group 6 and groups 1 and 2 statistically significant differences were observed.

Different level of CLA or sunflower oil addition into fodder did not influence statistical diversity of PUFA to SFA ratio. The lowest result (0.44) was observed in group 4. The highest ratio (0.57) was in group 6.

\section{Discussion}

Different results are presented by Eggert et al. (2001), who obtained more saturated fatty acids $(P \leq 0.001)$ and less unsaturated fatty acids $(P \leq 0.001)$ in Longissimus dorsi muscle of gilts fed with the fodder with the addition of conjugated linoleic acid. Similarly, Bee (2001) and Corino et al. (2003) stated that pigs receiving CLA had the fatty acid profile in their ham changed - more SFA, less MUFA. Barowicz \& Kędzior (2000) in their research also showed a significant increase in polyunsaturated fatty acids in Longissimus dorsi muscle lipids (PUFA). 
A significant increase in PUFA and a small decrease in the amount of SFA and MUFA were shown by Koczanowski et al. (2002) in their research. Walkiewicz et al. (2001) state that mutual relations between main fatty acids of intramuscular lipids of pigs - offspring of crossbred sows with the share of Siamese and PLW breeds and fathers of PL breed in different growth rate (body weight $10-50 \mathrm{~kg}$ ) were as follows: EFA level increased by $7 \%$, monoenic EFA showed a decreasing tendency (49.4-44.9\%), the level of polyenic acids increased: n-6 (11.6-13.5\%), the share of n-3 decreased (0.9-0.6\%). Václavková \& Bečková (2007) stated that feeding linseed to pigs significantly increased the content of linoleic acid $(P<0.05)$, a-linolenic acid $(P<0.001)$, arachidonic acid $(P<0.05)$ and eicosapentaenoic (EPA) acid $(P<0.05)$ content, but did not affect docosahexaenoic (DHA) acid content $(P>0.05)$ in muscle tissue $(M$. longissimus dorsi et thoracis). The $n-6 / n-3$ fatty acid ratio was lowered by the diet. The reduction was not statistically significant $(P>0.05)$. The content of total $n-6$ and $n-3$ fatty acids was the lowest in the control group.

Summarizing the results, it should be stated that in the present study, $0.5 ; 1.0 ; 2.0 \%$ addition of conjugated linoleic acid or sunflower oil in fodder dose did not influence the diversity of saturated and unsaturated fatty acids levels in Longissimus dorsi muscle.

\section{Acknowledgements}

The Research was carried out within the confines of V European Union Framework (Marie Curie Fellowship) in Ashtown Food Research Centre (Dublin, Ireland).

\section{References}

Barowicz T (2000) The effect of dietary Ca-fatty acid salts of linseed oil on cholesterol content in longissimus dorsi muscle of finishing pigs. In: „Quality of meat and fat in pigs as affected by genetics and nutrition«. Wenk C, Fernandez JA, Dupuis M (eds.), EAAP publicatication no 100, 225-228

Barowicz T, Kędzior W (2000) The use full-fat flax seeds and various vitamin E doses for modyfying the chemical composition and dietetic value of pork. Zesz Nauk PTZ 48, 161-174 [in Polish]

Bassaganya-Riera J, Hontecillas R, Beitz DC (2002) Colonic anti-inflammatory mechanisms of conjugated linoleic acid. Clinic Nutr 21, 451-459

Basu S, Smedman A, Vessby B (2000) Conjugated linoleic acid induces lipid peroxidation in humans. FEBSLetters 468, 33-36

Bawa S (2003) An update on beneficial role of conjugated linoleic acid (CLA) in modulating human health: mechanisms of action. Pol J Food Nutr Sci 12/53, 3-14

Bee G (2001) Dietary conjugated linoleic acid affect tissue lipid composition but not de novo lipogenesis in finishing pigs. Anim Research 50, 383-399

Corino C, Magni S, Pastorelli G, Rossi R, Mourot J (2003) Effect of conjugated linoleic acid on meat quality, lipid metabolism, and sensory characteristics of dry-cured hams from heavy pigs. J Anim Sci 81, 2219-2229

D'Souza DN, Mullan BP (2002) The effect of genotype, sex and management strategy on the eating quality of pork. Meat Sci 60, 95-101

Eggert JM, Belury MA, Kempa-Steczko A, Mills SE, Schinckel AP (2001) Effects of conjugated linoleic acid on the belly firmness and fatty acid composition of genetically lean pigs. J Anim Sci 79, 2866-2872 
Flis M, Sobotka W, Antoszkiewicz Z, Lipiński K, Zduńczyk Z (2007) Effect of husked and naked oat used in the diets supplemented with linseed oil on the growth performance of pigs carcass and meat quality. Arch Tierz $50 \mathrm{SI}, 161-171$

Hontecillas R, Wannemeulher MJ, Zimmerman DR, Hutto DL, Wilson JH, Ahn DU, Bassaganya-Riera J (2002) Nutritional regulation of porcine bacterial-induced colitis by conjugated linoleic acid. J Nutr 132, 20192027

Ip MM, Masso-Welch PA, Ip C (2003) Prevention of mammary cancer with conjugated linoleic acid: Role of the stroma and the epithelium. J Mamm Gland Biol Neoplasia 8, 103-118

Koczanowski J, Migdał W, Borowiec F, Klocek Cz (2002) Fatty acid profile in Longissimus dorsi muscle as an effect of different fatty acid composition in diets of fatteners slaughtered at different stages of fattening. Ann Anim Sci, Suppl. 2, 249-252

Kołodziej A, Pietruszka A, Jacyno E, Czarnecki R (2002) Relationship between meatiness, intramuscular fat and cholesterol content and fatty acids in pork meat. Ann Anim Sci, Suppl. 2, 325-329

Kritchevsky D (2000) Antimutagenic and some other effects of conjugated linoleic acid. Brit J Nutr 83, 459-465

MacDonald HB (2000) Conjugated linoleic acid and disease prevention: A review of current knowledge. J Amer Coll Nutr 19, 111-118

McCarty MF (2000) Activation of PPARgamma may mediate a portion of the anticancer activity of conjugated linoleic acid. Med Hypotheses 55, 187-188

Migdał W, Koczanowski J, Borowiec F, Furgał K, Barteczko J, Klocek CZ, Tuz R, Gardzińska A, Kurek M (1999) Effect of feeding on the fatty acid composition of loin and backfat in fatteners. Zesz. Nauk. AR Kraków, 67, Genetyczne i środowiskowe problemy w hodowli trzody chlewnej, Kraków, 28 września 1999, 199-207 [in Polish]

Migdał W, Koczanowski J, Paściak P, Borowiec F, Barowicz T, Pieszka M, Wojtysiak D, Orzechowska B, Klocek CZ, Tuz R (2004) Fatty acid profile in blood serum and in fat of ham and loin of cross-breed fatteners. Pr Mat Zoot, Zesz Spec 15, 239-240 [in Polish]

Missotten JAM, Claeys E, Raes K, De Smet S (2008) The influence of sow dietary PUFA source on the fatty acid profile of piglet tissues and blood and on piglet performance. Arch Tierz 51 SI, 32

Panczenko-Kresowska B, Ziemlański S (2001) Conjugated linoleic acid and its importance in pathological physiology. Żyw Człow Met 28, 61-70

Peinado B, Almela L, Duchi N, Poto A (2009) Effects of two different diets on carcass and meat quality traits of Chato Muriciano pigs. Arch Tierz 52, 150-160

Pfeuffer M (2001) Physiologic effects of individual fatty acids in animal and human body, with particular attention to coronary heart disease risk modulation. Arch Tierz 44, 89-98

Pieszka M, Paściak P, Barowicz T, Wojtysiak D, Pustkowiak H, Migdał W (2004) Effect of conjugated linoleic acid (CLA) addition to the diet on composition of fatty acids and lipids in pig blood. Ann Anim Sci, Suppl. 2, 165-170

Raj S, Skiba G, Weremko D, Fandrejewski H, Migdał W, Borowiec F (2004) Fatty acid composition of longissimus dorsi muscle in pigs as affected by breed and body weight. Pr Mat Zoot, Zesz Spec 15, $245-246$ [in Polish]

Statistica 8.0 PL (2008) StatSoft Polska

Václavková E, Bečková R (2007) Effect of linseed in pig diet on meat quality and fatty acid content. Arch Tierz $50 \mathrm{SI}, 144-151$

Walkiewicz A, Wielbo E, Matyka S, Babicz M, Dziubak A, Tochman L (2001) Effect of pig somatic development on a cholesterol content and fatty acid composition in pork. Zesz Nauk AR we Wrocławiu, Konferencje XXXI, nr 405, 255-261

Watkins BA, Seifert MF (2000) Conjugated linoleic acid and bone biology. J Amer Coll Nutr 19, 478-486 
Whigham LD, Higbee A, Bjorling DE, Park Y, Pariza MW, Cook ME (2002) Decreased antigen induced eicosanoid relase in conjugated linoleic acid fed guinea pigs. Amer J Physio 282, R1104-R1112

Więcek J, Rekiel A, Skomiał J (2010) Effect of feeding level and linseed oil on some metabolic and hormonal parameters and on fatty acid profile of meat and fat in growing pigs. Arch Tierz 53, 37-49

Received 5 August 2010, accepted 23 November 2010.

Corresponding author:

Przemysław Dariusz Wasilewski

email: surzwierz@utp.edu.pl

University of Technology and Life Sciences in Bydgoszcz, Faculty of Animal Breeding and Biology, Department of Animal Products Evaluation, Kordeckiego 20, 85-225 Bydgoszcz, Poland 